\title{
Sense of community, collective efficacy, and perceived police efficacy: Research from a social cognitive perspective
}

\author{
Ellen Belchior Rodrigues \\ West Virginia University
}

Follow this and additional works at: https://researchrepository.wvu.edu/etd

\section{Recommended Citation}

Rodrigues, Ellen Belchior, "Sense of community, collective efficacy, and perceived police efficacy: Research from a social cognitive perspective" (2010). Graduate Theses, Dissertations, and Problem Reports. 856.

https://researchrepository.wvu.edu/etd/856

This Thesis is protected by copyright and/or related rights. It has been brought to you by the The Research Repository @WVU with permission from the rights-holder(s). You are free to use this Thesis in any way that is permitted by the copyright and related rights legislation that applies to your use. For other uses you must obtain permission from the rights-holder(s) directly, unless additional rights are indicated by a Creative Commons license in the record and/ or on the work itself. This Thesis has been accepted for inclusion in WVU Graduate Theses, Dissertations, and Problem Reports collection by an authorized administrator of The Research Repository @ WVU. For more information, please contact researchrepository@mail.wvu.edu. 
Sense of Community, Collective Efficacy, and Perceived Police Efficacy: Research from a Social Cognitive Perspective

\title{
Ellen Belchior Rodrigues
}

\author{
Thesis submitted to the \\ Eberly College of Arts and Sciences \\ at West Virginia University \\ in partial fulfillment of requirements \\ for the degree of
}

\author{
Master of Arts \\ In \\ Sociology
}

Area of Emphasis in Applied Social Research

James Nolan, Ph.D., Chair

Jennifer Steele, Ph.D.

Ronald Althouse, Ph.D.

Division of Sociology and Anthropology

\author{
Morgantown, West Virginia \\ 2010
}

Keywords: Police, Sense of Community, Collective Efficacy, Human Agency, Community Policing, Situational Policing

Copyright 2010 Ellen Rodrigues 


\section{ABSTRACT \\ Sense of Community, Collective Efficacy, and Perceived Police Efficacy: Research from a Social Cognitive Perspective}

\section{Ellen Rodrigues}

This research investigates the relationship between two aspects of social cohesion on perceived police efficacy: 1) Sense of community, which is related to individual belonging and attachment to a place, as well as and trust and influence among residents; and 2) Collective efficacy, which is defined as cohesion among residents, combined with shared expectations for the social control of public spaces. Based in social disorganization theory and social cognitive theory, this study analyzes to what extent sense of community and collective efficacy affect perceptions of police work. This study was conducted in with residents from four neighborhoods from Wilmington, DE. Face-to-face household surveys were undertaken with randomly selected residents, resulting in 179 valid cases. Results show that collective efficacy was consistently the best predictor of perceived police efficacy. 


\section{ACKNOWLEDGMENTS}

The author wishes to express sincere appreciation to those that accompany her in the

journey towards the accomplishment of this degree. Special thanks to Professor James Nolan for all the support and encouragement, as well as Professors Jennifer Steele and Ronald Althouse for their assistance in the evaluation of this manuscript. 


\section{TABLE OF CONTENTS}

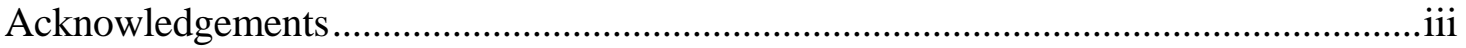

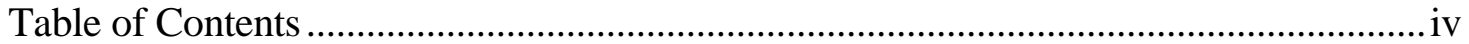

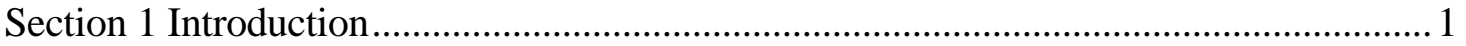

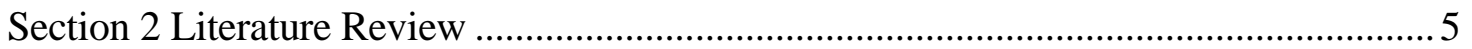

Section 3 Research Design and Methodology ............................................................ 19

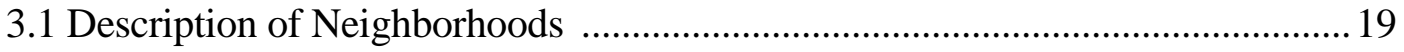

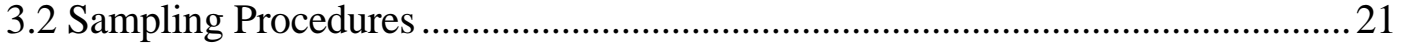

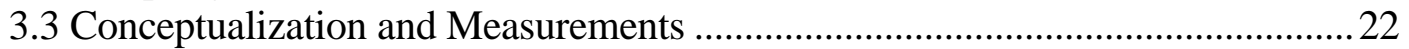

3.3.a Perceived police efficacy (Dependent Variable) .............................................22

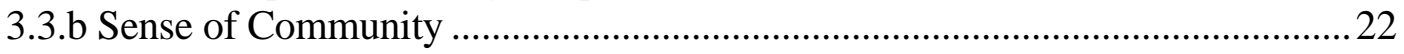

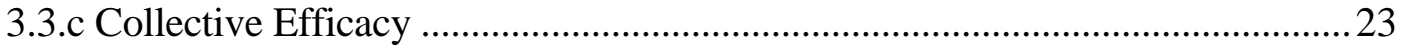

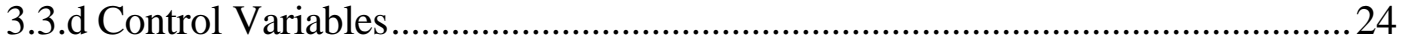

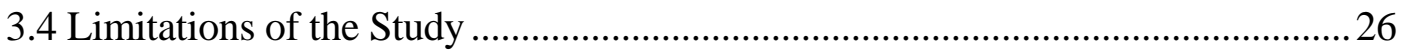

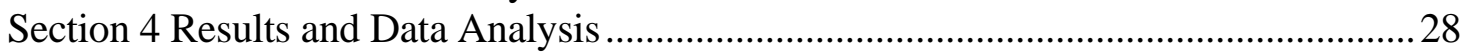

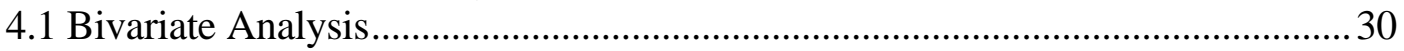

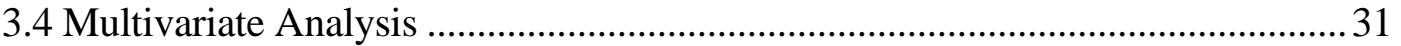

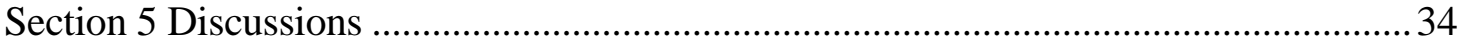

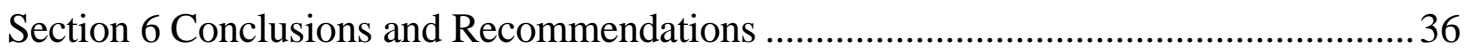

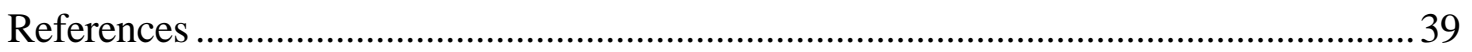




\section{INTRODUCTION}

It was another bright morning in the summer of 2007 when Ms. Katie saw me; she was tightening bamboo sticks on her fully grown tomato plants. She meant to go inside, but decided to go around the garden and meet me in front of her house. As I approached, she asked “so, what are all these kids from WVU doing here?” We were all part of a research team that was conducting surveys in neighborhoods in Wilmington. I was impressed with her interest and curiosity. I was getting used to residents clearly avoiding talking to us. Ms. Katie knew everything that was going on, and proudly listed all the church and community activities that she was involved with. While we talked, the police car slowly passed by. We had previously informed the police that we would be doing surveys in Wilmington. I attempted to ignore the police officer's insistence in making eye contact. Little did I know that he just wanted to wave at Ms. Katie.

By the end of the day the research team was now in another area of town. Mr. Rogers was coming back from work, rushing to lock his car and avoid being bothered by one of us, the "census people”. After I explained the purpose of the survey, he seemed willing to take it, but something was still making him uncomfortable. He suggested that we go inside his house, but we agreed to stay on the porch. He said he wasn't one of the best persons to fill out the survey. Despite living in the neighborhood for many years, "things were tough", he was just working hard, had no idea about what was going on, 
and barely had time to know his neighbors. I forgot to tell him that he would probably see police cars patrolling his neighborhood more often today because they were escorting us while we conducted surveys. When I least expected, a police car passed by and Mr. Rogers said appearing to be agitated "what? Are you with them?” After that he could no longer concentrate on finishing the survey without double checking where the “cops” were. After we finished he gave me this advice: “Girl, you better get out of here because it is getting dark".

Ms. Katie and Mr. Rogers had very different perspectives of the police. Despite several other factors that might account for such difference in opinion, I became specifically interested on their level of concern about what was happening around them. While Ms. Katie seemed to be very engaged in the community, Ms. Rogers confessed that he barely knew his neighbors. This observation brought many questions. First, is it possible that their level of involvement in the neighborhood affected the way they saw police? Perhaps people that have low involvement in the community are more skeptical of police work, whereas people who are engaged in their communities have a better perception of police.

The purpose of this study is to investigate whether "sense of community" and "collective efficacy" have an impact on perceptions of police efficacy. Urban and rural sociology have explored individuals' participation in their communities. For example, much has been written about the concepts "sense of community" and "collective efficacy" as a basis for understanding society in general. However, few have linked these two theoretical fields in an attempt to understand how dimensions of community involvement affect resident's relations with the police. 
The importance of examining the effects of sense of community and collective efficacy on perceived police efficacy lies on the fact that police need cooperation from residents to reduce crime, and the community needs the police at times. The principal of community policing resides on the cooperation between police and residents. If residents perceive police negatively, it is less likely that they would cooperate with police work, and ultimately police would not be effective in reducing crime.

Previous studies in criminal justice have explored the impact of various demographic components on perceptions of police service (Skogan, 1984; Hickman \& Simpson, 2003; Seron, Pereira, \& Kovath 2004). These studies often explore how individuals from different classes, genders, and races have varying opinions about police. The current study advances this investigation by including aspects of collective social strength.

The findings have implications for both academic and non-academic arenas. In the academic arena, it corroborates with studies in criminal justice and urban sociology. Regarding criminal justice, it engenders the development of effective tools for better relationship between police and society. As known, societal cooperation is vital to the strength of crime prevention policies. In the area of urban sociology, it facilitates the understanding of resident's feelings and beliefs about their community. By exploring the impact of sense of community and collective efficacy on perceived police efficacy, this study investigates which of these two aspects of social strength should be targeted in policies for community development.

Outside the academic arena, this study attempts to complement governments' initiative to establish community policing. Community policing is a strategy and 
philosophy based on the notion of interaction between police and community. Police rely on residents to know the issues that need special attention in the community. Therefore, police officers act as crime preventers.

By understanding whether sense of community and collective efficacy have an impact on how people perceive police work, neighborhood groups can improve relations with police, and police can improve community policing strategies.

The following section provides both a literature review and the theoretical development based on social disorganization theory and social cognitive theory. Section 3 , then describes the research design and methodologies. Section 4 examines the results and analysis of bivariate and multivariate data analysis. Section 5 presents a discussion of findings, and section 6 provides conclusion and recommendations. 


\section{LITERATURE REVIEW}

Over the years, police have increased their efforts to reach out to the community. The historical evolution of policing in United States shows how police have passed through three eras: political, professional, and recently the community policing era. The community policing approach, specifically, is based in a mutual effort between community and police officers to prevent crime.

One of the barriers encountered by police officers is the lack of cooperation from residents. Many residents are reluctant to cooperate with the police because they do not see them as a trustworthy institution. Unfortunately, in many cases, this is due to police officer’s biases towards minorities and lack of professionalism. However, characteristics from within the community might also be triggering such negative perceptions.

Social disorganization theory points to social forces in the environment affecting behavior and beliefs. For example, when people who live near each other are fearful because of high crime rates, they may not interact with their neighbors. When people avoid interacting, it causes a breakdown of informal social control, which is a potent tool in crime prevention. Sense of community and collective efficacy are examples of social forces that shape people’s beliefs. In this study, I investigate whether these social dynamics could be influencing what residents think about police work.

Past research points in the direction that community level efficacy beliefs could have an impact in overall relations with the government. Several studies show that social 
dynamics are linked with low levels of fear of crime (Walklate, 1998), low levels of crime and disorder (Sampson \& Raudenbush, 1999), high levels of political participation (Mutz, 2002), and high levels of citizen participation (Ohmer, 2007). Recently, Warner (2007) found that individuals that are more socially connected are more willing to solve problems on their own and be less dependent on the police.

Social cognitive theory also talks about efficacy beliefs. This theory points to the social power that groups and communities have to change things in positive ways once members believe in their collective ability to accomplish it. Thus, based in social disorganization theory and social cognitive theory, this study investigates whether in fact sense of community and collective efficacy have an impact on residents' perceptions about police work. Ultimately, it addresses the role of community residents in collaborating with the activities of the police, as well as the role of police in facilitating citizen's involvement in community policing.

The literature review is divided in an empirical and a theoretical part. The empirical part lays out the history of policing, the impact of social dynamics in human behavior, and the study's research questions and predictions. The theoretical part grounds such predictions according to social disorganization theory and social cognitive theory. 
Historical evolution of policing shows that contemporary police are attempting to reach out to the community and develop better relations with residents. The American police inherited three main characteristics from the British system: limited authority, local control, and fragmented organization (Cole \&Smith, 2009). The British government feared that a national force would threaten civil liberties. Therefore it assigned democratically elected members of Parliament to function as heads of the police departments among the regions. In the United States, during the Colonial Era and the Early Republic, cities began to hire paid, uniformed watchmen to deal with public danger and crime. However, in the South, these organized forces were used to prevent slave revolts and catch runaway slaves (Cole \& Smith, 2009).

Criminologists think of policing according to three policing eras: political, professional, and community policing eras. During what has come to be known as the political era (1840-1920), police became more involved with politics. A mayor's political party would appoint and recruit individuals to work in the police force, which in exchange helped the candidates during election time, and did not enforce laws on drinking, gambling, and prostitution. With the growth of cities, police became one of the few government institutions that had more familiarity with the complexities of problems on the streets. It caused a shift in police function from law enforcement to service provider. Police officers were expected to perform services related to emergencies and public health, such as caring for the homeless. Despite this slight shift in policing, functions related to law enforcement surpassed service functions.

The police attempted to shift away from politics by introducing the law enforcement model. The decades from 1920 to 1970 are known as the Professional 
Model Era because the police emphasized order maintenance and law enforcement. In order maintenance, police officers decided whether a law had been broken and what action should be taken. Thus, police officers acquired extreme power of discretion. It led to an increase in the incarcerated population, and various cases of abuse of power, racial profiling, and corruption. It also brought attention to the effectiveness of police work. Cole and Smith (2009) point that population became increasingly frustrated with police officers. Police were portrayed as crime fighters but crime rates kept increasing. Police could not change population's negative views regarding police effectiveness. Around the same time, public perception of policing gained broad media, political, and academic interest in the 1960s with the civil rights movement, urban riots, anti-war demonstrations, and social unrest. The law enforcement approach had not been successful in crime prevention. Instead, it represented an increase in expenditure, media attention, and reinforcement of negative views of police. Finally, with the introduction of the community policing approach, there was an expectation that police would be more effective in preventing crime.

The community policing era dates from late 1970 to the present. Advocates of this policing strategy claim that, instead of acting as crime fighters, police act to prevent crime and improve relations with individuals and communities. It meant also a focus on local services and use of a more citizen-friendly approach. Despite the popularity of this new approach, and the availability of federal funds for the development of community policing programs, studies show that American society is still frustrated and dissatisfied with police. 
Racial profiling is one of the strongest complaints about police. Crowley (2001) calls attention to the role of police in marginalizing ethnic minority groups from democratic participation. Skogan (2008) argues that police work is often shaped by stereotypes that economic elites have towards minorities. According to elite dominance theory, police are more likely to protect elites. Racial groups, i.e., Blacks and Latinos, are negatively targeted by police as being the dangerous classes and stopped for seizures and searches more frequently than Whites.

Looking at the influence of Black populations and police budgeting, Skogan (2008) found that jurisdictions hire more police and spend more money on them as the size of the Black population rises. However, variations in the size of the Black population did not affect expenditures when the percentages were small and presumably less threatening.

Part of the frustration with police also comes from the way police officers interact with the public. Tiersman and Solan (2004) write about the way the police approach individuals and use trick questions during investigations. According to them, the way police interact with the population and the ambiguity in their speech intimidates individuals and often implies a voice of command.

Often, people’s frustrations with police reflect their feelings about the government in general. Police are one of the most powerful government institutions. They are decentralized and visible (Skogan, 2008), locally controlled, funded, and staffed, are often patrolling the streets, and have the closest relation with residents. Cole and Smith (2009) argue that approximately 20 percent of Americans have had some type of encounter with a police officer. 
Other studies investigate whether characteristics from within the community, such as aspects of social dynamics, could be affecting people’s beliefs and behavior. In 1989, Sampson and Groves suggested that collective efficacy in the sense of friendship ties and neighborhood networks, inversely influence crime. Later, Walklate (1998) found that resident's relations with their local community and their level of involvement mediated the extent of fear of crime they might feel. In the following year, Sampson and Raudenbush (1999) found that lack of collective efficacy was consistently the most significant predictor of crime and disorder. Their study, widely known as the Chicago study, investigated 196 neighborhoods in terms of its observed and reported social disorder, crime, structural constraints, and collective efficacy. Taylor (2001) also found that these aspects of social dynamics were related with low crime rates. More recently, Warner (2007) studied the likelihood that individuals would either intervene in local problems or call the authorities to solve them. She showed that social ties increased the likelihood of direct informal social control (intervening), but not indirect informal social control (calling the authorities).

The current study investigates whether there would be a relation between social dynamics and individuals' perceptions of police efficacy. Although there is a gap in the literature regarding social dynamics and perception of police work, all these studies show that social dynamics, especially collective efficacy, have a great impact on people’s beliefs. Thus, could it be possible that social dynamics would also influence what people think about the police? As seen, social dynamics have been linked with less fear of crime (Walklate, 1998), more informal social control (Warner, 2007), and low crime rates (Sampson \& Raudenbush, 1999). Given this power of informal social control 
existent - but hidden - in communities, this study investigates whether individuals with two specific aspects of social dynamics - sense of community and collective efficacy would also have better perception of police work. Thus, the research questions and hypotheses of this study are stated as follow:

\section{Research Questions:}

1. What is the impact of sense of community on perceived police efficacy?

2. What is the impact of collective efficacy on perceived police efficacy?

3. Which of the two (sense of community or collective efficacy) is better predictor of perceived police efficacy?

\section{Hypotheses:}

$\mathrm{H}_{1}=$ There is a positive relationship between sense of community and perceived police efficacy.

$\mathrm{H}_{2}=$ There is a positive relationship between collective efficacy and perceived police efficacy.

$\mathrm{H}_{3}=$ Collective efficacy has a stronger impact than sense of community.

Most of the previous studies are grounded in social disorganization theory. This study not only makes use of principles from this sociological theory, but attempts to advance a psychological perspective through the use of social cognitive theory. Social disorganization theory is among the social ecology theories. This branch of sociological theories focuses on the environment surrounding the individual. Previous theoretical developments focused on the individual, its rational choices or abnormalities to explain behavior in society. Instead, social ecology theories contended that various forces in the environment come from physical, cultural, or social sources, and they all exerted influence in human behavior. Some indicators of social disorganization are high divorce rates, a large number of rental or vacant houses, and low residential stability. 
The theoretical development of social disorganization led sociologists to psychologists and specifically to Albert Bandura $(1989,2001)$ and his concept of collective efficacy (Sampson \& Raudenbush, 1999). More important than sense of community, collective efficacy is the bond that maintains communities. It is important to have a sense of community, but a sense of collective efficacy facilitates people working together. "Sense of community" and "collective efficacy" are a means by which residents can influence external social systems and work with neighbors and community organizations to improve their neighborhoods (Ohmer, 2007).

High levels of sense of community show internalization of moral values, while collective efficacy translates an assessment of responsibility towards the community. Sense of community is a feeling that members have of belonging, a feeling that members matter to one another and to the group and a shared faith that members' needs will be met through their commitment to be together (McMillan \& Chavis, 1986). Sampson and Raudenbush (1999) defined collective efficacy as cohesion among residents combined with shared expectations for the social control of public spaces. Both Sampson \& Raudenbush (1999) and Putnam (1995) found evidence of collective efficacy in stronger communities. But again, there is lack of research on how collective efficacy would relate to perceptions of police work.

Putnam (2004) also refers to the idea of collectiveness and social interaction. According to him, social networks are constructed from personal interactions that have consequences in a micro-level (the individual) and macro-level (society).The macrolevel - or collective efficacy - can be seen as the collective behavior towards a common goal for the benefit of the majority. Similarly, this study investigates whether lack of 
mutual trust or cooperation among residents affects their view of police and, ultimately, their ability to work together with police. It hypothesizes that an increase in sense of community and collective efficacy positively affect the way people perceive police work and their willingness to cooperate with police.

Social cognitive theory explores the idea of agency, one’s autonomy to make choices and exert control over the course of life, and also relating to shared beliefs among individuals of a certain group. The notion of shared beliefs was inaugurated in the early 1900s when psychologists investigated functioning of small groups. It was Emile Durkheim (1933) who introduced the idea of collective representation and social influence shaping individual's shared beliefs in society. It means that the individual him or herself does not control a belief, but the collective representation of a belief results from social participation and learning through socialization. Based on these principles, this research investigates individual's view of police as a shared belief among residents.

Collective representation is associated with the socialization process and active participation in society. Albert Bandura $(1989,2001)$ also explores the concept of societal beliefs. Bandura (2001) developed social cognitive theory based on the ideas of personal, proxy, and collective agency. According to him, levels of efficacy beliefs determine how personal, proxy, and collective agency develops and affect each other. Personal agency is determined by the level of self-efficacy. The level of self-efficacy belief directly affects ones' ability to conquer or hinder agency. When self-efficacy is low, signs of conflict, frustration, apathy, and avoidance appear.

This study focuses on proxy and collective agency. It investigates individual's perspectives and their relationships with institutions (police) and society 
(neighborhood). Proxy agency relates to individual's perceptions regarding the efficacy of institutions, authorities or experts. It is seen through the expectations one draws on the other. Individuals might develop a negative portrayal of institutions when expectations are not met. For example, when individuals think about the work of police, there is an expectation that police officers are competent and know what they are doing. Moreover, society expects police to protect them and keep them safe. In sum, once expectations are met, it translates into a good relationship between society and police.

Collective agency is a "property" shared by a group. Individuals share feelings and beliefs that determine their participation in the social engine. While personal agency refers to the individual's self-efficacy, and proxy agency to the efficacy of institutions, collective efficacy associates with the group’s efficacy. Social psychology research suggests that every group contains a sense of collective agency, which is either low, where individuals feel incapable of solving problems, or high, where proactive behavior is evident and individuals share a sense of responsibility.

Every group develops this characteristic of collectiveness and it can be either weak or strong. Studies in sociology and criminology have extended this assumption and found that neighborhoods can also be seen as a group where its residents share a sense of general capacity (Nolan et al., 2004; Sampson \& Raudenbush, 1999). Nolan et al. (2004) share that in these neighborhoods - in the psychological sense of groups - one will find 1) interdependence among members (i.e., what happens to one member is likely to affect all members), 2) frequency of contact, such that patterns of interaction between members occur (like a familiar wave or nod or small talk), 3) a recognition of members and non members, and 4) common goals (implicit or explicit). The authors also 
inaugurate a policing model based in crime rates and levels of collective efficacy. In the situational policing model, neighborhoods should be identified based on the analysis of crime rates and potential for interdependence with the police. Their investigation suggests four neighborhood types: Strong (low crime and high citizen participation), vulnerable (low crime and low citizen participation), anomic (high crime and low citizen participation), and responsive (high crime and high citizen participation), as shown in the following table:

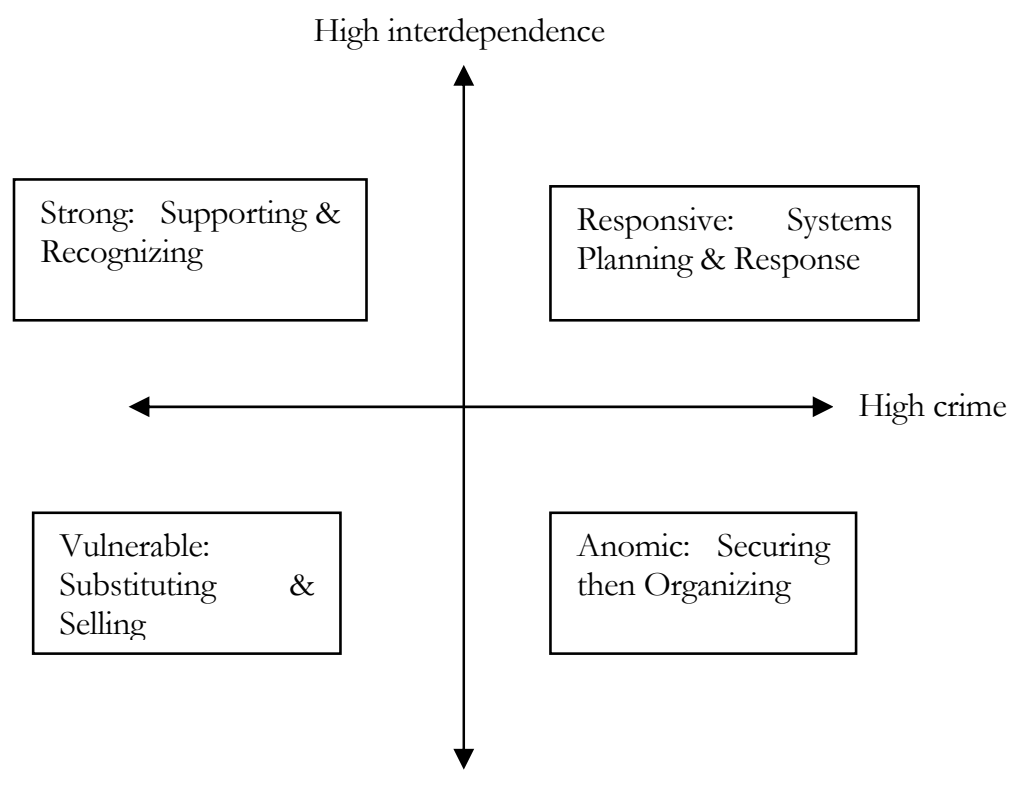

In order to enhance collective efficacy in strong neighborhoods, police should support and recognize individual community members or groups of members who have had particular successes in maintaining good outcomes. Vulnerable neighborhoods should be motivated to increase citizen participation, which could be done through cooperation with local institutions (nonprofit organizations, churches, neighborhood associations). Residents from anomic neighborhoods are characterized by their cynicism and lack of participation in the government. Consequently, police should publicize its 
efforts to fight crime in order to show responsiveness. In responsive neighborhoods, police should promote awareness of resident's ability to reduce crime. Police should help local groups to identify causes of crime. They should be able to create a shared vision for change and a coordinated action plan for effective change.

In social cognitive language, police are the proxy agents, on which society rely to provide protection and resolve problems they feel unable to solve. Sometimes the problem or desired change is more than an individual can handle and, therefore, they need help. Getting someone - an expert or government official or representative - to work on your behalf is referred to as proxy agency. Like proxy agency, collective agency is available to individuals and groups when issues of a magnitude above what can be handled by them alone.

An important aspect within this theoretical framework is the notion of efficacy beliefs which occur at all three levels of agency. When efficacy beliefs are high, success is more likely and people and groups remain hopeful. When efficacy beliefs are low, the opposite is true.

The issue at hand in this study is the ability to change perceptions of police by enhancing sense of community and collective efficacy in neighborhoods. We assume that in most cases the issues that create the environment for crime are beyond what an individual can fix him or herself. Therefore, if this environmental change is going to occur, it will either be because of the work of experts like the police (proxy agency) or everyone working together to create the type of place in which they want to live (collective agency). However, if residents see police work negatively, it is less likely that this transition would work. 
In conclusion, the following case illustrates how change in perceptions of police

allowed police to get cooperation from community. The negative portrayal of police delayed the implementation of a policy for crime prevention. On the other hand, the participation of society greatly contributed to the success of the establishment of community policing and consequent crime reduction.

During the apartheid regime, the South African police force implemented violent suppression of nonwhite political movements. Discrimination, repression, and subjugation were the policies practiced by the police, with violence and brutality as their weapons of choice. [..] In 1993, with the end of apartheid and the transition to multiparty democracy, policing in South Africa underwent a radical transformation, shifting away from a militaristic, authoritarian approach to policing, to one that aspired to greater community involvement. However, in spite of many legislative initiatives designed to stimulate greater trust in the police as impartial protectors of law and order, crime rates continued to dramatically increase. The growing disorder contributed to heightened fears about security and safety which predisposed politicians, the police, and the general public to favor implementing stringent law and order tactics rather than community policing strategies. In 1999, the reality of policing in South Africa differed from the legislative framework and it was evident that quite an extensive gulf had emerged between suggested policy and its implementation. Recognizing this gap, in 1999, the South African non-governmental organization (NGO) U Managing Conflict (UMAC) instigated a project which sought to illustrate that the advocated national policy of community policing could be an effective and feasible option, if only it were properly and fully implemented. UMAC developed Community Safety Forums to educate population and train most prospective individuals to facilitate implementation; established networks and linkages, both at the community level among fellow NGOs and with state, in order to identify feasible solutions. UMAC also sought support from media and public schools; and finally identified the most effective implementation plan per geographical area, which took about four years to be successfully completed (Tait 2004).

The case above shows the need for a radical change in the way society perceives police and how the police view society. Despite the attempt to shift from militaristic to community oriented approaches in policing, rampant crime rates and social disorganization hindered society’s feelings of safety and confidence in police. Policy implementation was only possible when communities joined forces with police in establishing community policing. This exercise of power in conjunction with the police 
is called collective agency. It is seen in groups, neighborhoods, and society. This power of integrated action was vital to the success of effective policing strategies in South Africa, and the shift towards more positive views of the police force. Thus, given the change in policing approach and emphasis of the community policing style, police have a role in improving its relation with society and facilitating society's collective efficacy.

Similarly, In United States, there is a need for better relations between police and society. Over the years police have put effort in improving relations with community, but several factors affect people’s perception of police work. This study investigates whether two indicators of social dynamics - sense of community and collective efficacy - have an impact on how people perceive police efficacy. They are evidences of informal social control and efficacy belief. They are components of group behavior and have a mutable nature. It means not only that they fluctuate over time, but most importantly, that they can be changed and improved. The breakdown of informal control, therefore, affects how residents "see” each other and the police. Only by recognizing the underlying dynamics can we understand more fully the manifest behavior that occurs. Finally, this study referred to two theoretical explanations: social disorganization theory (from sociology) and social cognitive theory (from psychology). By combining these two theoretical approaches I am advancing a societal psychological approach, in which the psychology and emotions of the collective become the focus.

The following section describes the research design and methodology of the study. 


\section{RESEARCH DESIGN AND METHODOLOGY}

\subsection{Description of Neighborhoods}

This study is based in the dataset of household neighborhood surveys conducted in Wilmington, DE during the summer of 2007. The principal investigator, Dr. Jim Nolan, purposefully selected the neighborhoods based upon differences in criminality rates, race-ethnic diversity, and apparent social cohesiveness among residents. The final selection yielded four neighborhoods: Eastside, Hilltop, Little Italy, and Forty Acres. Following are demographic characteristics and descriptions of each neighborhood according to Census 2000.

Table 1: Neighborhood Demographic Characteristics

\begin{tabular}{lllll}
\hline & $\begin{array}{l}\text { East } \\
\text { Side }\end{array}$ & $\begin{array}{l}\text { Forty } \\
\text { Acres }\end{array}$ & $\begin{array}{l}\text { Little } \\
\text { Italy }\end{array}$ & Hilltop \\
\hline Population & 2947 & 1614 & 2121 & 3468 \\
\hline Number of vacant houses & 221 & 38 & 133 & 179 \\
\hline Percent owned households & 19.2 & 60.9 & 51.9 & 47.4 \\
\hline Percent rentals & 80.8 & 39.1 & 48.1 & 52.6 \\
\hline Percent vacant houses & 13.7 & 4.3 & 12.5 & 16.5 \\
\hline Mean household income & 26857 & 61099 & 51338 & 32762 \\
\hline Median household income & 11490 & 46510 & 36250 & 30330 \\
\hline Median age & 32.9 & 33.7 & 39.8 & 27.7 \\
\hline Percent nonfamily households & 55.1 & 64.7 & 51.7 & 26.1 \\
\hline Percent households individuals under 18 & 33.3 & 13.3 & 24.9 & 52.9 \\
\hline Percent less than high school degree & 47.3 & 12.9 & 23.5 & 44.2 \\
\hline Percent female & 58 & 50.4 & 46.3 & 49.2 \\
\hline Percent White & 4 & 90 & 60.3 & 17.2 \\
\hline Percent Black & 92 & 7.5 & 31.7 & 48.7 \\
\hline Percent Hispanic & 4.8 & 2.1 & 9.9 & 45.2
\end{tabular}


Eastside: Considering the social demographic factors, Eastside has the most critical social setting. Only 19 percent of the houses were owned in 2000 and almost half of its population had less than high school degree. Despite the median age of 32.9, it had the lowest median household income.

Hiltop: Hiltop was the most populated neighborhood, with 3,468 residents. It has the youngest population and the median age is 27.7. In 2000, 52.9 percent of houses had individuals under 18. Little Italy has the lowest percentage of nonfamily households (26 $\%)$, and, therefore, a considerably low income per household $(\$ 32,762)$.

Little Italy: Little Italy has high mean household income $(\$ 51,338)$ and low number of individuals under 18 (24.9 \%) and with less than high school (23.5\%). It can be characterized as a neighborhood that is financially and socially stable. The median age is 39 and the population is racially diverse. The majority of the population is White (60.3\%), but there is a good percentage of Blacks (31.7\%) and Hispanic (9.9\%).

Forty Acres: Forty Acres is the wealthiest of the four neighborhoods. It has a relatively young population (median age $=33.7$ ) and the highest mean household income (\$61,099), which is higher than the mean household of Eastside and Little Italy. The majority of houses are owned (60.9\%). Few residents (12.9\%) have less than a high school degree. Forty Acres is also characterized by its low racial diversity, where 90 percent of the population $(1,614)$ is White. 


\subsection{Sampling Procedures}

Initially, researchers mapped the neighborhoods following boundaries defined by Census tracts. Each face block was numbered and then a sample of them was selected randomly. The research team, composed of approximately twelve interviewers, attempted to get responses from every house on the selected face block. Interviewers conducted face-to-face interviews with residents. Interviewers were required to read a cover letter, which contained information about the purpose of the study, assurances of confidentiality, and other relevant information. The team obtained approximately fifty questionnaires from each neighborhood, resulting in 179 valid cases. The following table compares percentages from Census 2000 with the data per neighborhood:

\begin{tabular}{ll|l|l|l|l|l|l|l} 
& \multicolumn{2}{c}{ Eastside } & \multicolumn{2}{c}{ Forty Acres } & \multicolumn{2}{c}{ Little Italy } & \multicolumn{2}{c}{ Hilltop } \\
\hline & Census & Sample & Census & Sample & Census & Sample & Census & Sample \\
\hline Population & 2947 & 51 & 1614 & 43 & 2121 & 41 & 3468 & 44 \\
\hline Owned households & $19.2 \%$ & $43 \%$ & $60.9 \%$ & $71 \%$ & $51.9 \%$ & $49 \%$ & $47.4 \%$ & $66 \%$ \\
\hline White & $4 \%$ & $2 \%$ & $90 \%$ & $91 \%$ & $60.3 \%$ & $62 \%$ & $17.2 \%$ & $23.5 \%$
\end{tabular}

In most cases, the sample is representative of the known parameters from the 2000 Census data. In Eastside, home owners were oversampled because researchers avoided house projects that were experiencing high crime rates.

The survey instrument had five pages and contained approximately 80 questions regarding sense of community, collective efficacy, attachment to neighborhood, civic engagement (political participation, civic participation, local engagement and local religious affiliation), safety, satisfaction with police, and victimization. This study targeted questions regarding perceived police efficacy, sense of community, and collective efficacy, besides the control variables. 


\subsection{Conceptualizations and Measurements}

\section{3.a Perceived police efficacy}

This variable is measured using five questions and an agreement scale ranging from 1-5, where 1 means “strongly disagree”, 2 means “disagree”, 3 means “neutral”, 4 means "agree”, and 5 means "strongly agree”. The five questions make a reliable scale with alpha value equal .850. An additive index was constructed, resulting in a scale ranging from 1 to 5. Respondents were asked how strongly they agreed or disagreed with the following questions:

1) The residents in my neighborhood can count on the police to protect them.

2) They are confident the police can keep them safe.

3) They believe the police know what to do.

4) They want the police to have enough resources to keep them safe.

5) They think the police are competent.

\section{3.b Sense of Community}

This variable measures level of trust and influence among residents. It is measured based on a scale developed by McMillan and Chavis (1986) and has Alpha value equal .721, indicating a reliable scale. The 13-item index measures sense of community based on four factors (group membership, influence, needs fulfillment, and emotional connection). The items were summed up and divided per thirteen, creating an index ranging from 0 to 1 . Negatively worded sentences were reversed during data analysis. Respondents were asked to indicate whether the following sentences are mostly true or mostly false, where mostly true was counted as 1 and mostly false counted as 0: 
1) I can recognize most of the people who live on my block;

2) I feel at home on this block;

3) Very few of my neighbors know me;

4) I care about what my neighbors think of my actions;

5) I have no influence over what this block is like;

6) If there is a problem on this block people who live here can get it solved;

7) I think my block is a good place for me to live;

8) People on this block do not share the same values;

9) My neighbors and I want the same things from the block;

10) It is very important to me to live in this particular block;

11) People on this block generally don't get along with each other;

12) I recognize a great many of the children who live in this neighborhood;

13) It is easy for me to identify "outsiders" in the neighborhood.

\section{3.c Collective Efficacy}

Through this variable I investigate the likelihood that neighbors would intervene in certain circumstances. Alpha value is .813 , indicating that this is a reliable scale. It uses the index developed by Sampson and Raudenbush (1999) to measure collective efficacy. The 5-item scale asked the likelihood that their neighbors would do something in given circumstances. Respondents were given 5 options to answer, where 1 means “very unlikely”, 2 means “unlikely”, 3 means “neutral”, 4 means "likely”, and 5 means "very likely". I constructed an additive index and the sum of all items creates a scale ranging from 5 to 25 . The questions were organized as follow:

1) If a group of neighborhood children were skipping school and hanging out on a street corner, how likely is it that your neighbors would do something about it?

2) If a fire station in your neighborhood was going to be closed because of budget cuts, how likely is it that people in your neighborhood would get together and do something about it? 
3) If some children were spray painting graffiti on a local building, how likely is it that your neighbors would do something about it?

4) If a child was showing disrespect to an adult in the neighborhood, how likely is it that people in your neighborhood would scold that child?

5) If there was a fight in front of your house and a child was being beaten or threatened, how likely is it that your neighbors would do something?

\section{3.d Control Variables}

\section{Race/Ethnicity}

In this study race is coded (1) if the respondent is White and (0) for non-Whites. Non-Whites include race identification Black and ethnic identification Hispanic. Out of the study sample of 179 individuals, 74 respondents self-identified as White, 83 as Black, and 20 as Hispanics.

\section{Household Income}

The study gave respondents the option to identify the household income in one of eight brackets, where 1 means an income of “less than \$20,000”, 2 means “between “\$20,000 and \$39,999”, 3 means “between $\$ 40,000$ and \$59,999”, 4 means “between “\$60,000 and \$79,999”, 5 means “between \$80,000 and \$99,999”, 6 means “between $\$ 100,000$ and \$119,999”, 7 means “120,000 and \$139,999”, and 8 means “above $\$ 120,000 ”$.

\section{Home ownership}

Respondents were asked whether they own, rent, or rent to own their houses. In the study 57 percent of the respondents own their houses and 43 percent rent them. I created a dummy variable to count only individuals that own houses. 


\section{Education}

Respondents were asked to indicate their level of education based on eight categories. The variable was recoded excluding the items "technical school certificate" and "other certificate" to yield six components. Thus, five percent of the respondents indicated that they have "less than high school”, 14 percent have "some high school”, 24 percent are "high school graduates”, 21 percent have some college, 22 percent are “college graduates”, and 14 percent have “post-graduate or professional degree”.

\section{Marital Status}

Out of the 179 individuals interviewed during this study, 41 percent were married, 48 percent single, two percent separated, and nine percent divorced. In this variable I only count as predictor the number of married individuals. Marital status is transformed into a dummy variable that counts (1) for married and (0) for all other categories.

\section{Employment}

Respondents were given five options for their employment status. Among the respondents, 65 percent are employed, nine percent unemployed, 17 percent retired, three percent are homemakers, and four percent are students. I created a dummy variable to include "employed” as one of the predictors for perceived police efficacy.

The following table is a summary of the variables under analysis, their measurements, and respective reliability scores: 


\begin{tabular}{|c|c|}
\hline Dependent Variable & \\
\hline Perceived Police Efficacy (1 - 5) & Alpha $=.85$ \\
\hline Independent Variables & \\
\hline Sense of Community (0-13) & Alpha $=.72$ \\
\hline Collective Efficacy (5 - 25) & Alpha $=.81$ \\
\hline Control Variables & \\
\hline Race & (1) White (0) Non-White \\
\hline Household Income & (1) “Less than $\$ 20,000 ”$ \\
\hline & (2) “Between “\$20,000 and \$39,999” \\
\hline & (3) “Between \$40,000 and \$59,999” \\
\hline & (4) “Between “\$60,000 and $\$ 79,999 ”$ \\
\hline & (5) “Between \$80,000 and \$99,999” \\
\hline & (6) “Between $\$ 100,000$ and $\$ 119,999$ ” \\
\hline & (7) “120,000 and \$139,999” \\
\hline & (8) “Above \$120,000”. \\
\hline Home ownership & (1) Own (0) Rent \\
\hline Education & (1) "Less than high school" \\
\hline & (2) “Some high school” \\
\hline & (3) "High school graduates" \\
\hline & (4) “Some college” \\
\hline & (5) “College graduates” \\
\hline & (6)“Post-graduate or professional degree” \\
\hline Marital Status & (1) Married (0) Not married \\
\hline Employment & (1) Employed (0) Not employed \\
\hline
\end{tabular}

\subsection{Limitations of the Study}

A limitation of the current study is that it does not address the impact of selfefficacy, the third component of social cognitive theory. It would be important to verify whether there is a relationship between self-efficacy and both collective efficacy and perceived police efficacy. It would allow better applicability of social cognitive theory not only in criminology but in sociology in general. Another limitation is that this work does not address perceptions of police officers about themselves and community. This 
analysis would allow the investigation of the hypothesis in both directions, not only the impact of social dynamics on police efficacy, but also how police officers perceive communities.

Finally, the study could not investigate how the impact of the independent variables on the dependent variable differentiates across neighborhoods. Considering that there are only four neighborhoods, the study aggregated the data pooled from each neighborhood and constrained in investigating only if there is a significant relationship between the independent variables and the dependent variable. 


\section{RESULTS AND ANALYSIS}

This study conducts bivariate and multivariate analyses using the Statistical Package for the Social Sciences (SPSS). The dependent variable is "perceived police efficacy”, which intends to measures individuals’ perceptions of police effectiveness. Higher scores of perceived police efficacy mean that respondents trust police and feel confident in their work. The independent variables are "sense of community" and “collective efficacy”.

For analysis purposes, this study aggregated the data from the neighborhoods in order to measure the relationship of the concepts under investigation. The aggregated data resulted in 179 cases. Despite pooling the data in one model, it was important to verify whether there were differences in mean scores across sites.

\begin{tabular}{lccc} 
Neighborhoods & $\begin{array}{c}\text { Sense of } \\
\text { Community (0-1) }\end{array}$ & $\begin{array}{c}\text { Coan Scores } \\
\text { Efficactive (5-25) }\end{array}$ & $\begin{array}{c}\text { Perceived Police } \\
\text { Efficacy (1-5) }\end{array}$ \\
\hline Eastside & .70 & 16.8 & 3.5 \\
\hline Hilltop & .69 & 16.6 & 3.4 \\
\hline Little Italy & .82 & 19.3 & 3.8 \\
\hline Forty Acres & .75 & 18.5 & 3.9 \\
\hline Total & .74 & 17.7 & 3.65
\end{tabular}

In terms of "sense of community” and “collective efficacy”, Little Italy stands out with the highest scores (respectively .82 and 19.3), followed by Forty Acres (.75 / 18.5), Eastside (.70 / 16.8), and Hilltop (.69 / 16.6). In terms of perceived police efficacy, Forty Acres has the highest score (3.9) and is followed by Little Italy (3.8), Eastside (3.5), and Hilltop (3.4). 
Although this study does not compare the neighborhoods, the possibility that the effects of the independent variables on the dependent variable vary somewhat at the neighborhood level is acknowledged.

It was also necessary to verify whether or not there was a high correlation between "sense of community" and "collective efficacy”. Results show that the Pearson correlation equals .266 and is significant at the 0.01 level. Thus, although there is a significant correlation between these variables, it is considered small and, consequently, excludes the possibility of multicolinearity.

Proceeding with the analysis, each of the independent variables and control variables will have its relation tested with the dependent variable through a linear regression. The results will be displayed in tables containing the beta coefficient, Rsquare or adjusted R-square, standard error, and significance, depending on whether it is a bivariate or multivariate analysis.

There are two data analysis tables. Table 1 shows the bivariate analysis between the dependent variable and each independent variable. It intends to show to what extent each independent variable, by itself, affects perceived police efficacy. Table 2 contains a multivariate analysis with correlation values between the dependent variable and all the independent variables It shows how this relationship changes when each control variable is added in the equation. They include the values of adjusted R-square, which shows the best model that explains change in the dependent variable. 


\subsection{Bivariate Analysis}

Table 1: Linear Regression Analysis with Perceived police efficacy

\begin{tabular}{lcc}
\hline & B & Significance \\
\hline $\begin{array}{l}\text { Independent Variables } \\
\text { Sense of Community }\end{array}$ & .993 & .001 \\
Collective Efficacy & .331 & .000 \\
$\begin{array}{l}\text { Demographics } \\
\text { White (0,1) }\end{array}$ & .260 & .032 \\
Household Income & .046 & .131 \\
Home ownership & .229 & .049 \\
Education & -.012 & .790 \\
Married & .275 & .035 \\
Employed & .046 & .835 \\
\hline
\end{tabular}

Among the eight independent variables, five are significantly related to the dependent variable when bivariate logistic regression was used: sense of community, collective efficacy, race (White), home ownership, and married. The relationship between the dependent variable and most of the independent variables is statistically significant. Only three variables did not present a significant relationship: household income, education, and employed. These results are consistent with this study's main hypotheses: that there is a positive and significant relationship between the dependent variable “perceived police efficacy”, and the independent variables “sense of community” and “collective efficacy”.

Regarding the control variables, I expected to find a positive and significant relationship with the dependent variable. However, education has a negative relation with perceived police efficacy. In addition, household income, education, and employed 
are not significant. I expected to find that individuals from high income families, those with high education, and those who are employed, would have a better portrayal of police as a legitimate and trustworthy institution. In sum, only race (White), home ownership, and married have an impact on the dependent variable. It means that three factors (1) being White, (2) owning a house, and (3) being married, reflect a positive portrayal of police.

Collective efficacy and perceived police efficacy have the most significant relationship, which is .000 . The R-square is .164, which means that collective efficacy itself explains 16.4 percent of variance in perceived police efficacy. More importantly, it has almost twice the R-square value of sense of community. It means that high levels of collective efficacy reflect better relationship with the police in terms of trust and confidence. It is not enough to be connected to the community in which the police work. In order for the police to obtain a sense of legitimacy and cooperation from society, it has to support the development of collective efficacy among individuals. It means that collective efficacy should be seen by police as an important tool to develop community policing. Next, table 2 will show the result of a multivariate analysis with all the independent and control variables.

\subsection{Multivariate Analysis}

A multivariate analysis is used to verify how adding variables to the equation affects the significance level and overall impact on the model. Table 2 shows the relationship between the dependent variable and all the independent variables. 


\section{Table 2: Multivariate Analysis}

Dependent Variable: Attitudes towards police

Independent Variables: Sense of Community, Collective Efficacy, Demographics

\begin{tabular}{|c|c|c|c|c|c|c|c|c|c|c|c|c|c|c|}
\hline & \multicolumn{2}{|c|}{ Model 1} & \multicolumn{2}{|c|}{ Model 2} & \multicolumn{2}{|c|}{ Model 3} & \multicolumn{2}{|c|}{ Model 4} & \multicolumn{2}{|c|}{ Model 5} & \multicolumn{2}{|c|}{ Model 6} & \multicolumn{2}{|c|}{ Model 7} \\
\hline & B & SE & $\beta$ & $\mathrm{SE}$ & $\beta$ & $\mathrm{SE}$ & B & SE & B & SE & $\beta$ & $\mathrm{SE}$ & B & $\mathrm{SE}$ \\
\hline SOC & .177 & .339 & .161 & .345 & .224 & .337 & .219 & .322 & .413 & .310 & .501 & .345 & .338 & .346 \\
\hline C.Efficacy & $.330 * * *$ & .070 & $.327^{* * *}$ & .072 & $.312 * * *$ & .070 & $.275^{* * *}$ & .067 & $.221^{* *}$ & .066 & $.226 * *$ & .073 & $.265 * *$ & .082 \\
\hline White $(0,1)$ & & & .169 & .118 & .152 & .142 & .100 & .135 & .132 & .134 & .139 & .156 & -.026 & .162 \\
\hline Hh Income & & & & & .019 & .033 & .013 & .033 & .040 & .038 & .054 & .041 & .055 & .044 \\
\hline Own House & & & & & & & .117 & .122 & .129 & .120 & .117 & .135 & .273 & .149 \\
\hline Education & & & & & & & & & -.079 & .059 & -.100 & .064 & -.098 & .071 \\
\hline Married & & & & & & & & & & & -.005 & .127 & -.119 & .140 \\
\hline Employed & & & & & & & & & & & & & .216 & .278 \\
\hline Adj. R2 & Model $1=$ & & Model 2= & & Model 3= & & Model 4=. & & Model $5=.1$ & & Model 6= & .186 & Model 7= & .238 \\
\hline
\end{tabular}

* Significant at .05 level

** Significant at the .01 level

*** Significant at the .001 level 
This is the most important table of this study because it shows the impact of collective efficacy on sense of community. As observed on the previous table, sense of community had a positive and significant relationship with perceived police efficacy. When collective efficacy was added in the equation, sense of community was no longer significant. On the other hand, collective efficacy continued with positive and significant association with perceived police efficacy in all the following models. The significance level remained .001 until model 4, when it was analyzed with the variables sense of community, White, household income, and home ownership. It dropped to .01 when education, married, and employed were respectively introduced. Model 7 is the one that best predicts an impact on the dependent variable. The Adjusted- $\mathrm{R}^{2}$ value of .238 means that it explains 23.8 percent of change in perceived police efficacy. In conclusion, collective efficacy has the most significant relationship with perceived police efficacy. 
Section 5

\section{DISCUSSION}

This study examined two dynamic aspects of neighborhood that may affect how residents perceive and ultimately behave in their relationship with police. Why is it important? First, sociologists (Sampson and Raudenbush 1999), among others have found that "collective efficacy” was inversely related to crime in neighborhoods. Where collective efficacy was high, crime was low and vice versa.

Although a view of the relationship between crime and collective efficacy was beyond the scope of this study, I did find that collective efficacy predicted positive attitudes toward the police. Therefore, not only is it advisable for police to participate in efforts to build neighborhood level efficacy as a crime prevention strategy, but it is also smart because when crime does occur, and when the police organization needs the support of the community, it is more likely to happen when high levels of collective efficacy exists.

In addition, collective efficacy was defined as cohesion among residents plus shared expectations for social control. Whereas sense of community represents more of the single aspects of belongingness/cohesion, it appears that with regard to positive perceived police efficacy, this is only part of the equation.

From a community relations standpoint, it would be better for police departments to work with community on both cohesion and shared expectations for social control, rather than just the prior. 
From the social cognitive perspective, efficacy beliefs is an individual own ability to create a positive change or beliefs in the "proxy", i.e., expert or authority, or in the collective are what keep groups positive and hopeful and motivated. I see "perceived police efficacy” as a measure of proxy efficacy. Do residents think the police are going to be able to have positive results preventing and responding to crime? It seems from the findings that the beliefs in the proxy - police - are very much related to beliefs in the collective. From these findings it does not appear that the police alone would be as successful in helping residents see them as effective and believe in them as if police worked on building collective efficacy instead.

The results show that despite the effect of sense of community on perceptions of police work, collective efficacy excelled all the results. Collective efficacy itself explains 16.4 percent of variance in perceived police efficacy. It means that people with higher collective efficacy are more supporting and trusting of police, believe the police know what they are doing, and believe police should have better resources. In sum, sense of community is an important predictor, but collective efficacy is the most important predictor of perceived police efficacy in this study. An individual that actively engages in the community and does something towards a common benefit is more likely to have better perception of police efficacy than those that have sense of community, own houses, are well educated, and well employed. 


\section{CONCLUSION AND RECOMMENDATIONS}

This study investigated the relationship between perceived police efficacy, sense of community and collective efficacy. It attempted to untangle whether sense of community and collective efficacy had an impact on perception of police service. In order to understand such relationship, it employed social disorganization theory and social cognitive theory.

The relevance of this study is twofold. First, it advances the understanding that community policing may be the best way the police can improve relations with neighborhoods. Community policing reactivates components of social dynamics that reinforce informal social control and collective efficacy beliefs.

Second, this study highlights the difference between sense of community and collective efficacy. While sense of community is based on sense of belonging to the place and socialization among residents, collective efficacy is based on willingness to solve problems together. These are two similar aspects of social cohesion, but this study found that collective efficacy is a best predictor of perceived police efficacy.

By investing in a group’s collective efficacy, police can improve relations with society. As stated in social cognitive theory, every group develops a sense of collective agency which can either be weak or strong. When individuals feel capable of solving

problems, proactive behavior is evident and individuals share a sense of responsibility. 
Future studies should focus on how collective efficacy could be improved in a neighborhood level. The theoretical part of the literature review pointed to a typology of community policing called situational policing (Nolan et al., 2004), where the authors suggest different strategies depending on levels of crime and collective efficacy. Similarly, this research contends that the same suggestions can be carried on to neighborhoods with high (strong, and responsive) and low (vulnerable and anomic) levels of collective efficacy. It is important to verify such differences in order to have better report from community. For example, if the police go knocking on doors asking for information in a neighborhood with low levels of collective efficacy, residents might feel threatened and develop a negative relation with police. On the other hand, in neighborhoods with high levels of collective efficacy this strategy might be seen as competence and responsiveness.

Thus, in order to preserve collective agency in strong neighborhoods, police should support and recognize "individual community members or groups of members who have had particular successes in maintaining good outcomes. Vulnerable neighborhoods should be motivated to increase citizen participation. It can be done through cooperation with local institutions (nonprofit organizations, churches, neighborhood associations), which are often interested in promoting voluntary engagement. Residents from anomic neighborhoods are characterized by their cynicism and lack of participation in the government. Consequently, police must publicize its efforts to fight crime in order to show responsiveness. Finally, in responsive neighborhoods police should promote awareness of residents' ability to engage and act collectively. Police should help local groups to identify causes of crime. They should be 
able to create a shared vision for change and a coordinated action plan for effective change.

Perhaps many people are still skeptical of community policing because they are not able to see its preventive aspect. Failures on the implementation of community policing could also be because police officers were either focusing on enhancing sense of community, or not observing the community's level of collective efficacy. The ultimate claim of this work, therefore, is that besides the use of community policing, and focus on collective efficacy, there is a need for different approaches and styles.

In sum, police should be looking at how much people care about a certain problem; whether they can identify what is causing the problem; if their behavior (anomic, i.e.) is part of the problem or contributes to it; whether they are willing to address a problem; and the reasons why they would not be interested in solving these problems. Residents often seem disinterested, but in fact they feel incapable of promoting social change. They need to be encouraged to think that their behavior within the community can affect reality in perceiving solutions.

The overall suggestion is to use a situational policing approach to enhance collective efficacy. Understanding of people’s feelings and beliefs about their neighborhoods allows the police to frame neighborhood characteristics and choose effective ways to engage the community. By studying a community’s sense of efficacy, it is possible to identify what the best strategy to address various social issues would be. Collective efficacy might also work as a determinant of public support for governmental decisions, including the work of the police. On the other hand, the lack of this understanding might lead to a negative view of police or delay in policy implementation. 


\section{REFERENCES}

Bandura, Albert. "Social Cognitive Theory: An Agentic Perspective.” Annual Review Psychology 52.1 (2001): 1-26.

Barker, Mary H., Barbara C. Nienstedt, Ronald S. Everett, and Richard McCleary. "The Impact of a Crime Wave: Perceptions, Fear, and Confidence in the Police.” Law \& Society Review 17.2 (1983): 319-335.

Brodsky, Anne E., and Christine M. Marx. "Layers of Identity: Multiple Psychological Senses of Community within a Community Setting." Journal of Community Psychology 29.2 (2001): 161-178.

Browning, Christopher R., Seth L. Feinberg, and Robert D. Dietz. "The Paradox of Social Organization: Networks, Collective Efficacy, and Violent Crime in Urban Neighborhoods.” Social Force, 83.2 (2004): 503-534.

Chavis, David M. and Grace M. H. Pretty. "Sense of Community: Advances in Measurement and Application.” Journal of Community Psychology. 27.6 (1999): 635642.

Chipuer, Heather M. and Grace M. H. Pretty. "A Review of the Sense of Community Index: Current Uses, Factor Structure, Reliability, and Further Development.” Journal of Community Psychology. 27.6 (1999): 643-658.

Cole, George E. and Christopher E. Smith. "Police”. Social Construction of Justice: A New Approach to Understanding Crime, Criminality, and Criminal Justice. Ed. L. Paul Sutton. San Diego: Cognella/University Readers. 2009.

Crowley, John. T. “The Political Participation of Ethnic Minorities.” International Political Science Review 22.1 (2001): 99-121.

Donnelly, Patrick G., and Theo J. Majka. "Resident’s Efforts at Neighborhood Stabilization: Facing the Challenges of Inner-City Neighborhoods.” Sociological Forum 13.2 (1998): 189-213.

Einstadter, Werner J. and Stuart Henry. Criminological Theory: An Analysis of its Underlying Assumptions. Oxford, UK: Rowman \& Littlefiled, 2006.

Friedman, Warren. "The Community Role in Community Policing." The Challenge of Community Policing: Testing the Promises, Ed. Dennis P. Rosenbaum. Thousand Oaks, CA: Sage Publications, 1994. 263-269. 
Galanter, Marc. "Why the Haves Come Out Ahead: Speculations on the Limits of Legal Change.” Law and Society Review. 9.1 (1974): 95-116.

Goering, John M. “Towards a National Policy for Neighborhoods: A Conversation between a Policy Maker and a Social Scientist.” Public Administration Review 40.6 (1980): 553-560.

Graddy, Elizabeth A., and Donald L. Morgan. "Community Foundations, Organizational Strategy and Public Policy.” Nonprofit and Voluntary Sector Quarterly. 35.4 (2006): 605-630.

Hartnagel, Timothy F. "The Perception and Fear of Crime: Implications for Neighborhood Cohesion, Social Activity, and Community Affect.” Journal of Social Forces, 58.1 (1979): 176-193.

Hawden, James. "Legitimacy, Trust, Social Capital, and Policing Styles: A Theoretical Statement.” Police Quarterly 11.2 (2008): 182-201.

Hickman, Laura J. and Sally Simpson. "Fair Treatment or Preferred Outcome? The Impact of Police Behavior on Victim Reports of Domestic Violence Incidents." Law and Society Review 37.3 (2003): 607-634.

Hill, Jean L. "Psychological Sense of Community: Suggestions for Future Research." Journal of Community Psychology 24.4 (1996): 431-438.

Kelling, George L. and Catherine Coles. Fixing Broken Windows: Restoring Order and Reducing Crime in Our Communities. New York, NY: Toutchstone. 1996.

Kin, Yong-Chan \& Ball-Rokeach, Sandra J. “Community Storytelling Network, Neighborhood Context, and Civic Engagement: A Multilevel Approach.” Human Communication Research 32 (2006): 411-439.

La Due Lake, Ronald, and Robert Huckfeldt. "Social Capital, Social Networks, and Political Participation.” Political Psychology 19.3 (1998): 567-584.

Lawless, Jennifer L. and Richard L. Fox. "Political Participation of the Urban Poor." Social Problems 48.3 (2001): 362-385.

Liska, Allen E., Joseph J. Lawrence, and Andrew Sanchirico. "Fear of Crime as a Social Fact.” Journal of Social Forces 60.3 (1982): 760-770.

Lyons, William. The Politics of Community Policing. Ann Arbor, MI: U of Michigan. 1999.

McMillan, David W., and David M. Chavis. "Sense of Community: A Definition and Theory.” Journal of Community Psychology 14 (1986): 6-23. 
Moore, Mark Harrison. "Problem-Solving and Community Policing.” Crime and Justice 15 (1992.): 99-158.

Mutz, Diana. C. "The Consequences of Cross-Cutting Networks for Political Participation.” American Journal of Political Science 46.4 (2002): 838-855.

Nolan, James J., Norman Conti and Jack McDevitt. "Situational Policing: Neighborhood Development and Crime Control.” Policing \& Society 14.2 (2004): 99-117.

Obst, Patricia L. and Katherine M. White. "Revisiting the Sense of Community Index: A Confirmatory Factor Analysis.” Journal of Community Psychology 32.6 (2004.): 691705.

Ohmer, Mary. “Citizen Participation in Neighborhood Organizations and its Relationship to Volunteers' Self- and Collective Efficacy and Sense of Community.” Social Work Research 31.2 (2007):109-120.

Ohmer, Mary. "Citizen Participation in Neighborhood Organizations in Poor Communities and its Relationship to Neighborhood and Organizational Collective Efficacy.” Journal of Sociology and Social Welfare. 30 (2007):119-133.

Peterson, Andrew N., Paul W. Speer and Joseph Hughey. "Measuring Sense of Community: A Methodological Interpretation of the Factor Structure Debate.” Journal of Community Psychology 34.4 (2006.): 453-469.

Putnam, Robert D. “Bowling alone: Americas’ Declining Social Capital.” The Journal of Democracy 6.1 (1995): 65-78.

Putnam, Robert. Bowling Alone: The Collapse and Revival of American Community. New York, NY: Simon \& Schuster Paperbacks. 2000.

Sampson, Robert J., Stephen W. Raudenbush, and Felton Earls. "Neighborhoods and Violent Crime: A Multilevel Study of Collective Efficacy.” Science 227.5328 (1997): n. pag. Web. 1 February, 2008.

Sampson, Robert J., and Stephen W. Raudenbush. "Systematic Social Observation of Public Spaces: A New Look at Disorder in Urban Neighborhoods.” The American Journal of Sociology 105.3 (1999): 603-651.

Sampson, Robert J., and Stephen W. Raudenbush. "Seeing Disorder: Neighborhood Stigma and the Social Construction of "Broken Windows.”Social Psychology Quarterly 67.4 (2004): 319-342.

Seron, Carroll, Joseph Pereira and Jean Kovath. “Judging Police Misconduct.” Law and Society Review 38.4 (2004): 665-710. 
Shaw, Clifford R., and Henry D. McKay. Juvenile Delinquency and Urban Areas: A Study of Delinquents in Relation to Differential Characteristics of Local Communities in American Cities. Chicago: U of Chicago 1942.

Skogan, Wesley G. “Communities, Crime, and Neighborhood Organization.” Crime \& Delinquency 35.3 (1989): 437-457.

Skogan, Wesley G. “Citizen Satisfaction with Police Encounters.” Police Quarterly 8.3 (2005): 298-321.

Skogan, Wesley G. "Criminal Justice and the Police.” The Oxford Handbook of Law and Politics. Ed. Keith E. Whittington, R. Daniel Kelemen, and Gregory A. Caldeira. Oxford, Oxford University. 2008. 615.

Tait, Sean. Impacting on Community Policing Policy: South Africa. NGOs at the Table: Strategies for Influencing Policies in Areas of Conflict. Oxford, UK: Rowman \& Littlefield, 2004. 113-128.

Taylor, Ralph B. and Margaret Hale. "Criminology: Testing Models of Fear Of Crime.” The Journal of Criminal Law \& Criminology 77.1 (1986): 151-189.

Taylor, Ralph. B. "The Ecology of Crime, Fear and Delinquency: Social Disorganization versus Social Efficacy.” In Explaining Criminals and Crime, Ed. Raymond Paternoster and Ronet Bachman. Los Angeles, CA: Roxbury, 2001. 124-139.

Thornton, Leonard M. "People and the Police: An Analysis of Factors Associated With Police Evaluation and Support.” Canadian Journal of sociology 1.3 (1975): 325-342.

Tien, James M. and Thomas F. Rich. “The Hartford COMPASS Program: Experiences with a Weed and Seed-related Program.” The challenge of Community Policing: Testing the Promises, Ed. Dennis P. Rosenbaum. Thousand Oaks, CA: Sage, 1994. 192-206.

Tiersma, Peter M. and Lawrence M. Solan. "Cops and Robbers: Selective Literalism in American Criminal Law.” Law and Society Review 38.2 (2004): 229-266.

Tyler, Tom R. "Psychology and the Law." The Oxford Handbook of Law and Politics. Ed. Keith E. Whittington, R. Daniel Kelemen, and Gregory A. Caldeira. Oxford University, 2008. 117.

Walklate, Sandra. “Crime and Community: Fear or trust?” British Journal of Sociology 49.4 (1998): 550-569.

Warner, Barbara D. "Directly Intervene or Call the Authorities? A Study of Forms of Neighborhood Social Control within a Social Disorganization Framework.” Criminology 45.1 (2007): 99-129. 
Weisburd, David and John E. Eck. "What Can Police Do to Reduce Crime, Disorder, and Fear?”ANNALS, AAPSS 593 (2004): 42-65.

Weitzer, Ronald and Steven A. Tuch. "Determinants of Public Satisfaction with the Police.” Police Quarterly, 8.3 (2005): 279-297.

Wilson, James Q. and George L. Kelling. “Broken Windows.” The Atlantic Online. (1982): 1-9. 